\title{
Artykuey
}

KLIO. Czasopismo poświęcone dziejom Polski i powszechnym

PL ISSN 1643-8191, t. 23 (4)/2012, s. 117-128

Mateusz Wyżga

(Kraków)

\section{Korespondencja miasta Krakowa w XVII-XVIII wieku}

$\mathrm{P}$ rzechowywane w Archiwum Państwowym w Krakowie księgi korespondencji miasta Krakowa w dobie staropolskiej stanowią bogaty i interesujący materiał badawczy. „Libri Epistolarum Urbis Cracoviae” nie cieszyły się dotąd większym zainteresowaniem badaczy i nie powstało ich opracowanie monograficzne ${ }^{1}$. Ich wartość dla historii Krakowa jest jednak istotna.

Najdawniejsza korespondencja miasta nie była wpisywana do odrębnych ksiąg. Księgi korespondencji zostały zaprowadzone przez kancelarię miejską dopiero w 1621 r. $^{2}$ Sporządzano w nich kopie wysłanych i odebranych przez magistrat listów z okresu od 10 maja 1621 do 16 sierpnia 1797 r., przy czym korespondencji wychodzącej jest znacznie więcej. Księgi te obejmują 5403 strony w 20 tomach ${ }^{3}$. Początkowo listy wprowadzano bez ustalonego formu-

${ }^{1}$ Księgi są przechowywane po sygnaturami 1307-1357; Katalog archiwum aktów dawnych miasta Krakowa, t. 2: Rękopisy, Kraków 1915, s. XVIII, 173-178.

2 O organizacji kancelarii miasta Krakowa zob.: M. Friedberg, Kancelaria miasta Krakowa do potowy XVIII wieku, „Archeion” 1955, t. 24, s. 277-304; o kancelarii miasta Krakowa zob. również: B. Wyrozumska, Kancelaria miasta Krakowa wśredniowieczu, Kraków 1995; Z. Noga, Urzędnicy miejscy Krakowa. Część 2: 1500-1794, Kraków 2008, s. V-LI.

3 Liber epitolarum [1621-1712]; [1712-1727]; Compendium listów ad magnates regni i IchMciów różnych pisanych ab anno Domini 1728 [1728-1730]; Liber epistolarum ad varios magnates et proceres tum protectores urbis huius Cracoviae [1741-1751]; [1764-1769]; Listy i expedycye w różnych interesach miasta Krakowa pisane... [1771-1772]; Listy, memoryały i expedycye w interesach miasta Krakowa $\mathrm{z}$ responsami pisane i indukowane... [1772-1773]; Listy i różne expedycye w interesach miasta Krakowa od szlachetnego magistratu do JWW. Protektorów i innych 
larza i są przemieszane chronologicznie. Dopiero około 1697 r. zaczęto dbać o większy porządek w aktach. W 1774 r. pojawiło się w tytule ksiąg nazwisko pisarza ${ }^{4}$. Dopiero w 1776 r. nastąpił podział w obrębie poszczególnych tomów na korespondencję wychodzącą i przychodzącą.

Wydaje się, że krakowskie „Libri epistolarum” gromadzą listy większej wagi. Prócz ksiąg korespondencji zachowało się bowiem jeszcze 31 fascykułów akt luźnych z lat 1540-1797, grupujących listy w oryginałach, często z kopertami i lakowymi odciskami pieczęci, pisane na różnej wielkości papierze, niekiedy bez adresata czy datacji.

\section{Wykres 1. Korespondencja wychodząca z miasta Krakowa w latach 1626-1725 (w okresach 25-letnich)}

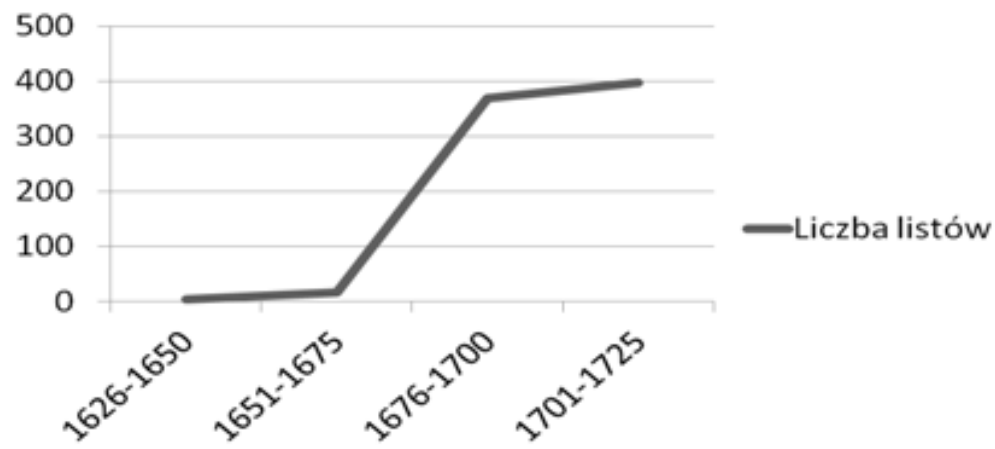

Źródło: APKr., Libri epistolarum urbis Cracoviae, sygn. 1307, 1308.

W księgach korespondencji jest kilka luk chronologicznych, obejmujących łącznie 27 lat (1730-1741; 1751-1764; 1769-1771). Fascykuły natomiast charakteryzują się ciągłością od 1681 do 1797 r. Ogólnie stan zachowa-

osób pisane przez mnie Andrzeja Orłowskiego syndyka tegoż miasta wraz z responsami indukowane [1774-1775]; w dalszym porządku nastąpiło rozdzielenie ksiąg korespondencji na listy wysłane i odebrane (sygn. 1315-1326). Przykładowo w latach 1776-1777 wyglądało to w następujący sposób: a) Intytulacje do memoriałów i listów; b) Listy i różne expedycye w interesach miasta Krakowa do różnych JJ. WW. Panów pisywane przezemnie Filipa Lichockiego, syndyka miasta tegoż a die obrania siebie to iest a die 22 Junii 1776; c) Listy i różne expedycye w interesach do miasta Krakowa pisywane, przezemnie zaś F. Lichockiego ... indukowane [1776-1777]; Katalog archiwum aktów..., s. 173-176.

${ }^{4}$ W 1774 r. syndyk Andrzej Orłowski, w 1776 r. - syndyk Filip Lichocki, późniejszy rajca i prezydent, a 1781 r. kancelarzysta Kasper Męciszewski, późniejszy rajca; Z. Noga, Urzędnicy miejscy Krakowa..., nr 920, 921, 386. 
nia omawianej kolekcji źródłowej należy oszacować jako dobry. Moje uwagi oparłem na analizie dwóch ksiąg korespondencji z lat 1621-1727 oraz fascykule aktów luźnych z lat 1543-1680, zawierających około 1000 listów.

$\mathrm{Z}$ rozpoznanych materiałów źródłowych wynika, że $90 \%$ korespondencji wpisanej do ksiąg na przełomie XVII i XVIII wieku to listy wychodzące z magistratu. Liczba rejestrowanych w kancelarii kopii listów systematycznie rosła, co zostało zilustrowane na wykresie 1 . Największy wzrost wystąpił w ostatniej ćwierci XVII wieku.

Najwięcej pism miasto skierowało do osób zwanych „protektorami”, „obrońcami” lub „patronami”, którymi byli urzędnicy centralni, urzędnicy województwa, a także dostojnicy Kościoła. Odbiorcy byli „zasypywani” skargami i zażaleniami na stan miasta, ciężkie kontrybucje i straty wynikłe z rąk żołnierzy, czy też uchylanie się obcych kupców przed prawem składu. Zabieganie o protekcję miało też inną odsłonę - magistrat zapewniał o swojej przyjaźni, którą odpowiednio opłacał. Przykładowo w 1718 r. w liście do pisarza wielkiego koronnego Hieronima Jełowickiego czytamy: „20 talarów bitych [...] upraszamy, raczysz one za wdzięczne przyjąć, a na interesa miejskie zawsze być pamiętny i łaskaw" "W listach posłowie miejscy otrzymywali instrukcje, jak postępować z „patronami”. We wspomnianym roku przedstawiciele miasta Andrzej Szafałkowicz i Michał Awendyk

szczęśliwie stanąwszy [na sejm w Grodnie] oddadzą wizytę jaśnie oświeconym [...] senatorom, dygnitarzom i urzędnikom, osobliwym miasta tego protektorom przy doniesieniu należytej veneracji ${ }^{6}$.

Nadto pilnowano wysyłania wspomożycielom tzw. listów gratulacyjnych „z powinszowaniem”, zwykle z okazji Nowego Roku czy Świąt Bożego Narodzenia ${ }^{7}$.

Przeszło połowę listów rada miasta Krakowa skierowała do dostojników Kościoła (zwłaszcza do biskupa krakowskiego), kasztelanów, kanclerza wielkiego koronnego, wojewodów i króla. W przypadku urzędu kasztelana najczęstszymi odbiorcami oprócz kasztelanów krakowskich (otrzymali 38\% listów wysłanych do kasztelanów) byli kasztelanowie wojniccy (36\% listów; dosyć regularna korespondencja od 1694 r.). Do kasztelanów często słano zażalenia

5 APKr., Libri epistolarum urbis Cracoviae, sygn. 1308, s. 130.

${ }^{6}$ Ibidem, s. 145.

7 Np. APKr., Libri epistolarum..., sygn. 1307, s. 344. 
na działalność wojsk albo proszono o obniżenie podatku z powodu zubożenia miasta. W 1720 r. pisano do kasztelana krakowskiego i hetmana wielkiego koronnego Adama Mikołaja Sieniawskiego: „jęczy i stęka pod obligacjami Kraków". Natomiast spośród korespondencji do wojewodów poza krakowskimi (43\% listów złożonych na ręce wojewodów) zaznaczył się udział wojewodów bełskich (18\%) i sieradzkich (13\%). Szczegółowe zestawienie odbiorców korespondencji zawiera został tabela 1.

Tabela 1. Listy wysłane z magistratu krakowskiego w latach 1642-1724

\begin{tabular}{|l|c|c|}
\hline \multicolumn{1}{|c|}{ Odbiorca } & Liczba bieżąca & Odsetek (w \%) \\
\hline Kościól & 97 & 12,28 \\
\hline Kasztelanowie & 73 & 9,24 \\
\hline Kanclerz wielki koronny & 67 & 8,48 \\
\hline Magistraty innych miast & 64 & 8,1 \\
\hline Wojewodowie & 61 & 7,72 \\
\hline Król & 58 & 7,34 \\
\hline Starostowie & 27 & 3,42 \\
\hline Podkanclerzy koronny & 23 & 2,91 \\
\hline Podskarbi wielki koronny & 20 & 2,53 \\
\hline Żony urzędników & 14 & 1,77 \\
\hline Pisarze & 11 & 1,39 \\
\hline Miecznicy & 11 & 1,39 \\
\hline Marszałek nadworny koronny & 10 & 1,27 \\
\hline Marszałek wielki koronny & 10 & 1,27 \\
\hline Osoby prywatne & 4 & 0,51 \\
\hline Inne & 159 & 20,15 \\
\hline Nierozpoznane & 81 & 10,25 \\
\hline Ogólem & & 100 \\
\hline & & \\
\hline
\end{tabular}

Źródło: APKr., Libri epistolarum urbis Cracoviae, sygn. 1307, 1308.

8 Ibidem, sygn. 1308, s. 178. Wiadomo, że w podanym roku przeprowadzono lustrację kamienic w Krakowie. Podsumowanie rabunkowej gospodarki lat wielkiej wojny północnej ukazało wielkie zubożenie miasta; J. Bieniarzówna, J. M. Małecki, Dzieje Krakowa, t. 2: Kraków w wiekach XVI-XVIII, Kraków 1984, s. 457. 
Pojawia się również korespondencja do krewnych urzędników, głównie małżonek: kasztelanowej krakowskiej czy radomskiej, kanclerzyny wielkiej koronnej, hetmanowej wielkiej koronnej, wojewodziny bełskiej i kaliskiej. To dowód na poszukiwanie przez magistrat dodatkowej protekcji. Przykładowo w 1723 r. po liście wysłanym do kanclerza wielkiego koronnego Jana Sebastiana Szembeka zabiegano o wsparcie jego żony, matki i siostry, skoro wszystkie wysłały listy do kanclerza o względy dla miasta. Czytamy słowa matki:

Na samym wyjeździe moim z Krakowa do Kraszyny przyszli do mnie Ichmościowie Panowie Radzcy Miasta Krakowskiego, potrzebując instancji mojej do WMPana....

Z kolei żonę kanclerza udało się rajcom spotkać z okazji odbywającego się sejmiku w Proszowicach. W 1707 r., prawie w tym samym czasie (31 sierpnia i 20 września) pisano do wojewody bełskiego i jego żony w sprawie wyprowadzenia garnizonu z Krakowa w obliczu "plagi boskiej powietrznej"10. W 1720 r. magistrat zwrócił się do kasztelanowej krakowskiej o skarcenie jej dworzanina o nazwisku Morycki, dłużnika krakowianina Jana Kluga, którego pod własną kamienicą, po próbie polubownego załatwienia sprawy „pan Morycki w gębę pięścią uderzył, aże mu się krew rzuciła”" ${ }^{11}$ Starania o protekcję bywały udane. W 1718 r. do wojewody krakowskiego Janusza Antoniego Korybuta Wiśniowieckiego zwrócono się z wdzięcznością:

Prawie jakby słońce zajaśniało w progach naszych $[\mathrm{z}]$ miłościwej protekcji waszej książęcej mości, pana dobrodzieja naszego ${ }^{12}$.

Prawie co dziesiąty list wprowadzony do księgi był adresowany do innych miast. Korespondencja ta w dużej mierze dotyczyła kwestii handlowych. Często jej przedmiotem było omijanie prawa składu, jak na przykład w 1700 r., kiedy magistrat wystosował takie pismo „do różnych miast koronnych, osobliwie Lwowa, Lublina, Warszawy" ${ }^{13}$. Można też wskazać na wstawiennictwa za kupcami krakowskimi w innych miastach, ostrzeżenia przed zbliżającym się

\footnotetext{
9 APKr., Libri epistolarum..., sygn. 1308, s. 240.

${ }^{10}$ Ibidem, sygn. 1307, s. 507.

11 Ibidem, sygn. 1308, s. 172.

12 Ibidem, s. 159.

13 Ibidem, sygn. 1307, s. 427.
} 
powietrzem morowym oraz $\mathrm{w}$ sprawach prywatnych o charakterze matrymonialnym, rodzinnym (porzucenie dziecka), długów, zabójstwa, uwięzienia krakowianina $\mathrm{w}$ innym mieście ${ }^{14}$.

\section{Wykres 2. Listy wysłane z Krakowa do innych miast (1643-1723)}

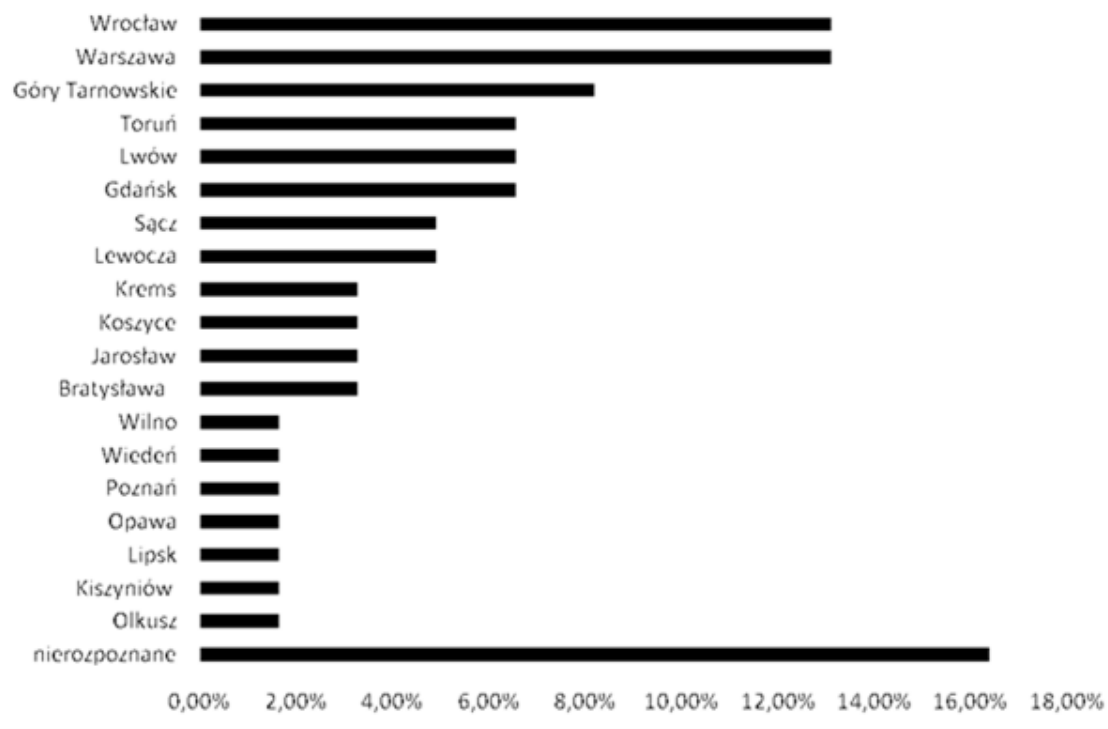

Źródło: APKr., Libri epistolarum urbis Cracoviae, sygn. 1307, 1308.

Drobna korespondencja władz miasta z osobami prywatnymi, głównie z rajcami, kupcami i szlachtą w zdecydowanej większości znajduje się w fascykułach. Zawiera skargi, prośby o pomoc i wstawiennictwo, wyjaśnienia zobowiązań finansowych. Przykładowo w 1705 r. do magistratu spłynęło wiele listów mieszczan z zażaleniami na garnizon szwedzki stacjonujący w Krakowie. Pojawiają się w tej korespondencji także sprawy obyczajowe. Ich ilustracją może być list Agnieszki Zayfretowej do burmistrza i rady miejskiej z 9 marca 1700 r., zawierający prośbę o pomoc w kłopotach małżeńskich:

14 Wśród korespondencji wysłanej z Krakowa do magistratu Gór Tarnowskich w latach 1691-1692 pojawiła się sprawa o morderstwo i o porzucenie dzieci w Krakowie przez matkę, która w Górach Tarnowskich zawarła ponowne małżeństwo; APKr., Libri epistolarum..., sygn. 1307, s. $200 \mathrm{i}$ nn. 
Nie inkaustem, ale krwawemi prawie łzami moją wielką dolegliwość opisać mi przychodzi do Świątobliwego Sądu WMMM Panów ${ }^{15}$.

Zachowały się też pospolite donosy.

Tabela 2. Wprowadzone do ksiąg miejskich listy przychodzące (1621-1724)

\begin{tabular}{|l|c|c|}
\hline \multicolumn{1}{|c|}{ Nadawca } & L.b. & \% \\
\hline Kościół & 22 & 30,99 \\
\hline Król & 21 & 29,58 \\
\hline Kanclerz wielki koronny & 3 & 4,23 \\
\hline Inne miasta & 3 & 4,23 \\
\hline Wojewoda sieradzki & 2 & 2,82 \\
\hline Wojewoda krakowski & 2 & 2,82 \\
\hline Inne & 13 & 18,31 \\
\hline Nierozpoznane & 5 & 7,04 \\
\hline Ogółem & 71 & 100 \\
\hline
\end{tabular}

Źródło: APKr., Libri epistolarum urbis Cracoviae, sygn. 1307, 1308.

Jedynie 10\% poddanej badaniu korespondencji wprowadzonej do ksiąg to listy przychodzące. Większość pochodzi z kancelarii kościelnych, zwłaszcza od biskupów krakowskich. Wiele sporządzono w kancelarii królewskiej, następnie u kanclerza wielkiego koronnego i w kancelariach innych miastach.

15 APKr., Libri epistolarum..., sygn. 1308, s. 21. W liście jest mowa o kilkunastu latach upodlenia, bicia, odbierania pieniędzy, które mąż wolał „z kompanią przepić”. Nieco wcześniej niejaka Marianna Waxmanowa prosiła o zapomogę, skarżąc się na skąpego i nieżyczliwego męża, który nazbyt „dufał sekcie swojej kalwińskiej” (11 V 1695). Interesująca jest korespondencja towarzysza chorągwi husarskiej Wojciecha Kempskiego z burmistrzem krakowskim Stanisławem Cyrusem o przywrócenie żołnierzowi dobrego imienia po pijackiej burdzie z chłopami podkrakowskimi (16 II 1674); APKr., Libri epistolarum..., sygn. 1308, s. 21, 9, 80. O problemach z wojskiem świadczy również przykład z 1680 r., kiedy miasto złożyło skargę na towarzysza chorągwi husarskiej wojewody kijowskiego Teodora Maszkiewicza, który najechał powracających wieczorem z rodzinami z folwarku podmiejskiego lonera Antoniego Lukiniego i doktora Stanisława Wosińskiego, zaczął strzelać do ich powozu, a także ciął woźnicę szablą. W tej sprawie list skierowano do hetmana wielkiego koronnego Dymitra Jerzego Wiśniowieckiego oraz wspomnianego wojewody; APKr., Libri epistolarum..., sygn. 1308, s. $130 \mathrm{i} \mathrm{nn.}$ 
Należy również wspomnieć o korespondencji pisanej w sprawie Krakowa przez protektorów miasta, które rzetelnie kopiowano do krakowskich ksiąg, jak choćby epistoły biskupa krakowskiego do króla ${ }^{16}$. Dodajmy, że księgi korespondencji zawierają także instrukcje dla posłów miasta Krakowa na sejm ${ }^{17}$, a także projekty listów. Udało się też odnaleźć kopię listu, jaki magistrat sporządził do publicznego ogłoszenia kupcom w sprawie obowiązującego w Krakowie prawa składu (1680).

Listy były przekazywane na wiele sposobów: przez pocztę, posłów miejskich, kupców, a wreszcie umyślnie do tego posyłanych ludzi, co było powszechną praktyką. Z kupcami ustalano termin ich wyjazdu i w odpowiednim czasie przekazywano im korespondencję, zaznaczając w treści listu imiennie, kto list dostarczy. Na przykład w 1707 r. rajcy wzmiankowali w liście do wojewodziny bełskiej:

Gdy się nam przez pana Rydla podała okazja że do Warszawy wyjeżdża, nie omieszkaliśmy [...] niniejszym pisaniem donieść...,

a jej mężowi:

odezwaliśmy się przez umyślnego z uniżoną prośbą naszą listownie do [...]

Pana oznajmując o zaczętej w mieście pladze boskiej powietrznej.

Innym razem czytamy o wysłaniu „umyślnego sztafetki”18.

Listy przekazywano też furmanom. W 1613 r. posłowie miejscy Krzysztof Szober i Hieronim Bełza pisali z Warszawy do Krakowa:

Pewniśmy tego, że to pisanie już Waszym Miłościom doszło przez furmana Sileczę.

Innym razem znajdujemy słowa Jana Waxmana adresowane do burmistrza i rady miejskiej Krakowa z Warszawy:

${ }_{16}$ W 1721 r. biskup krakowski Konstanty Felicjan Szaniawski po prośbach magistratu krakowskiego wysłał list na trybunał koronny do Lublina: „List do trybunału za miastem Krakowem [...] miasto Kraków ozdoba Królestwa naszego...”; APKr., Libri epistolarum..., sygn. 1308, s. 203.

17 Zob. przyp. 6.

18 Ibidem, sygn. 1307, s. 502-509; sygn. 1308, s. 246. 
pisałem Waszmościom przez górnika, który szedł do Olkusza, który list włożyłem w list JmCi Pana Wizemberga (1624).

W 1680 r. list królewski przekazał do magistratu podrzędczy zamku krakowskiego ${ }^{19}$.

Czas przesyłki był jak wiadomo zależny od szeregu czynników ${ }^{20}$. Niekiedy da się go obliczyć. Na przykład w 1718 r. list od kasztelana wojnickiego Franciszka Dembińskiego szedł z Radomia do Krakowa cztery dni. Warto też zwrócić uwagę na czas, w jakim odpowiadano na listy. Często magistrat sporządzał responsy bez zwłoki, jeszcze w dniu otrzymania korespondencji. W ten sposób pisano do kanclerza wielkiego koronnego Jana Szembeka: „Dnia dzisiejszego doszła nas wiadomość” (1723) ${ }^{21}$. Ale niekiedy trwało to dłużej (np. po 6 dniach wysłano w 1661 r. odpowiedź do Samuela Świderskiego marszałka Związku Święconego) ${ }^{22}$. Z kolei magistratowi gdańskiemu odpowiedziano po 14 dniach. Działo się to w 1719 r. w czasie panoszącej się zarazy ${ }^{23}$. Marszałek niepłaconych od kilku lat wojsk skonfederowanych Bogusław Baranowski pisał 1 marca 1697 r. do Krakowa z Sambora w sprawie wypłacenia subsydiów, a już 8 marca wysłano mu odpowiedź ${ }^{24}$. Z kolei 10 dni szedł list od posłów miejskich z Warszawy (1621), w którym informowali o zagrożeniu granicy przez Turków. Średnia prędkość przenoszenia listów wynosiła 25 kilometrów dziennie. Potwierdzają to pojedyncze przykłady, w tym list królewski wysłany zimą 1534 r. z Wilna. W grudniu 1704 r. list z Torunia do Krakowa szedł 12 dni $^{25}$.

19 Ibidem, sygn. 1328, s. 71 i nn.

${ }^{20}$ Z badań Wacława Urbana wynika, że niekiedy dziennie pokonywano odległość przekraczającą 40 kilometrów. Nadto przemieszczanie się spowalniały roztopy, powodzie, działania wojenne albo powietrze morowe; W. Urban, Kursowanie listów polskich w dobie przedpocztowej, „Przegląd Humanistyczny" 1992, t. 4, s. 67-71. Organizowana od 1558 r. poczta była szybkim przekazicielem informacji. W $1723 \mathrm{r}$. magistrat krakowski dowiedział się o miejscu pobytu jednego z dygnitarzy od kuriera z Wrocławia; APKr., Libri epistolarum..., sygn. 1308, s. 266.

${ }^{21}$ APKr., Libri epistolarum..., sygn. 1308, s. 243.

22 Ibidem, sygn. 1307, s. 17 i nn.

${ }^{23}$ Ibidem, sygn. 1308, s. 163.

${ }^{24}$ Ibidem, sygn. 1307, s. 399. Za miastem wstawił się kasztelan krakowski Stanisław Jabłonowski. Wsparcia szukano też u biskupa krakowskiego. Trwała wymiana korespondencji. Ostatecznie sprawę załagodzono na sejmiku proszowickim; J. Bieniarzówna, J. M. Małecki, op. cit., s. 440-442 .

25 „Od PP Torunczan przeczytany die 13 decembris 1704”; APKr., Libri epistolarum..., sygn. 1307, s. 467; Z badań Jany Vojtíškovej nad korespondencją czeskich miast królewskich w końcu XVI wieku wynika, że najwięcej listów rejestrowano w październiku i listopadzie; eadem, Písem- 
Ale list sporządzony w ratuszu przyległego miasteczka Kazimierz i podpisany przez jego burmistrza Marcina Gizowskiego do burmistrza krakowskiego Kacpra Guttetera otwarto dopiero po dwóch dniach $(1599)^{26}$. W badanej kolekcji znajdujemy korespondencję pomiędzy rajcami. Te listy dostarczano szybko. Adresowana do burmistrza Jana Fryzynkiera nota od „brata i kollegi” Stanisława Segnitza z wyjaśnieniem kontrowersji wokół płacenia Szwedom trybutu została przeczytana jeszcze tego samego dnia (14 III 1704) ${ }^{27}$. Wreszcie można wyodrębnić listy „polecone”. Wyróżniają się odpowiednią adnotacją na kopercie: „cito oddać”, „w pilne oddanie”, „do rąk własnych oddać”, „pilno oddać należy w Krakowie"28.

Wiele listów nie posiada nadawcy ani adresata. Z kolei brak adresu doręczenia dotyczy zwłaszcza królów i duchownych. Mogli nadawać i odbierać listy $\mathrm{w}$ miejscach, gdzie akurat przebywali. Wiadomo przykładowo, że w sierpniu 1679 r. magistrat sporządzał odpowiedź na list królewski przysłany ze Lwowa. W końcu XVII wieku listy w księdze są przemieszane chronologicznie w obrębie kilku lat. Ujednolicona zasada kancelaryjna wykształciła się dopiero w drugiej połowie następnego stulecia, kiedy każdy wpisany do księgi list ma na marginesie nadawcę, miejscowość odbiorcy oraz tematykę listu, a całość w porównaniu do wcześniejszego okresu znacząco uporządkowano. Przy niektórych kopiach dopisano na marginesie: ad depositorium lub „do Wieży”. Pojawiają się też w księgach wpisy błędne (po wprowadzeniu zapiski przekreślone), a także luki, niekiedy sama tylko intytulacja. Na marginesach widnieją noty adresowe w stylu: „Do Lublina”, „Do Poznańczanów”, „Do Sądeczanów”, „Na Góry Tarnowskie”, „Do Torunian”, „Do Urzędu Jarosławskiego”. Skopiowany list zawierał intytulację, dopiski na marginesie o treści, dacie i adresacie przesyłki, dalej treść korespondencji, a na końcu informację o nadawcy. W listach poruszano nurtujące miasto kwestie: wysokość podatków, zagrożenia wojenne i przemarsze wojsk, spory z Żydami kazimierskimi, niepłacenie należnego cła, omijanie przez kupców prawa składu. Miasto powoływało się na przyznane mu przywileje. Uwagę zwraca nieraz pełna ekspresji forma listu, zwłaszcza dotyczących

ná komunikace mezi českými královskými mèsty v doběprèedbělohorské na príkladu Nového Mèsta pražského a polabského pètimèstí, Praga 2011, s. 102.

26 APKr., Libri epistolarum..., sygn. 1328, s. 81.

27 Ibidem, s. 100 i nn.

28 Przykładowo 10 sierpnia 1640 r. Andrzej Janocki pisał do Mikołaja Pipana, wójta Prawa Wyższego Zamku Krakowskiego w sprawie sądowej Wójtowiczów, a na kopercie zaznaczono: „cito oddać”; Libri epistolarum..., APKr., sygn. 1328, s. 115. 
trudnego położenia miasta. W 1712 roku pisano do króla „z krwawym płaczem, nieustającym jęczeniem" z miasta osłabionego epidemią i nadmiernym wysiłkiem finansowym utrzymywania garnizonu wojskowego ${ }^{29}$, innym razem składano „płaczliwe supliki udręczenia” albo skarżono się: „toż miasto przez powietrza i inne zachodzące publiczne calamitates zniszczone”.

Przez pryzmat korespondencji Krakowa możemy śledzić wzajemne ostrzeganie się miast przed nadciągającą zarazą. W ten sposób w latach $1704-$ -1705 magistrat krakowski odebrał szereg monitów od Lwowa, Wrocławia, Warszawy i Gdańska ${ }^{30}$. O epidemii ostrzegali też listownie królowie. Zachował się interesujący zbiór listów, które w obliczu nadciągających wojsk szwedzkich magistrat Krakowa w dniach 4-7 sierpnia 1655 r. wysłał do króla, marszałka wielkiego koronnego Jerzego Lubomirskiego, kanclerza wielkiego koronnego Stefana Korycińskiego, wojewody krakowskiego Władysława Dominika Zasławskiego, kasztelana krakowskiego Stanisława Warszyckiego, pewnych senatorów z prośbą o pomoc przy obronie miasta ${ }^{31}$.

W niektórych przypadkach poza wyrazem „protektorze”, „dobrodzieju” nie wiadomo, do kogo pismo było zredagowane. Nie odnalazłem informacji na temat samej praktyki wprowadzania do ksiąg kopii listów, chociaż pojawiają się na marginesach, na przykład wykazy poprawnej intytulacji. Wiadomo dalej, że wpisy jednocześnie sporządzało przynajmniej dwóch pisarzy.

Należy teraz wspomnieć o języku, w którym prowadzono korespondencję. Większość zbadanych listów była pisana po polsku. Korespondencja z papiestwem, nuncjuszem i biskupami (w większości) i innymi miastami była prowadzona przeważnie po łacinie. Listy w języku niemieckim były tłumaczone i wpisywano do księgi zarówno w jego oryginalnym języku, jak i w tłumaczeniu, np. list z Pilzna z 1702 r. $^{32}$

29 „Dawno, z krwawym płaczem, nieustającym jęczeniem, pospolitym nas ludzi ubogich skwierkiem, do majestatu waszej królewskiej mości, pana naszego wysyłamy, w uciskach nieznośnych, nie wypisanych, które bez wytchnienia, ustawicznie cierpimy. Niedola nasza, że na tak częste supliki żadnej uprosić, wyjednać sobie ulgi, miłosierdzia i respektu nie możemy...”. List ów kończą słowa: „płakać, całować, ściskać leżąc u nóg WKM nie przestaniemy, a co skwierczemy, wyżebrzemy. Wierni poddani Burmistrz i Rada Stołecznego Miasta Krakowa”; APKr., sygn. 1328, s. 20 i nn; J. Bieniarzówna, J. M. Małecki, op. cit., s. 455.

30 APKr., sygn. 1328, s. 119-125v.

31 APKr., sygn. 1307, s. 11-16. Jeszcze 2 sierpnia burmistrz Krakowa Andrzej Cieniowicz oznajmił zebranym na ratuszu mieszczanom plan obrony, a rada miejska wystosowała wspomniane listy; J. Bieniarzówna, J. M. Małecki, op. cit., s. 363.

32 APKr., sygn. 1307, s. 447. 
W korespondencji przejawia się troska rady o dobro miasta, widać zabieganie u najwyższych urzędników państwowych i kościelnych o popieranie spraw Krakowa. Wyłania się strategia polityki miasta, w tym poszukiwanie protekcji u dostojników państwowych. Listy te odzwierciedlają również bieżące problemy gminy miejskiej. Dopiero analiza pełna, obejmująca również oryginalne listy przechowywane w fascykułach, da nam pełny ogląd sytuacji.

\section{Correspondence of the City of Cracow in the Seventeenth and Eighteenth Century \\ (Summary)}

Books of correspondence were introduced by Cracow municipal office in 1621 . Approximately $90 \%$ of the letters are correspondence sent from the city hall. Most of the letters were directed to influential persons, called "patrons". They were central and province officials, dignitaries of the Church. They were mainly informed about the problems of the city. More than half of the letters were received by clergymen (especially the Bishop of Cracow), castellans, Chancellor of the Crown, provincial governors and the king. The city council also wrote to their relatives. Only $10 \%$ of letters were sent to other cities. These were mainly trade related issues. Most of the letters to private persons were not entered into the books. On the other hand registered incoming letters come mostly from the office of the Bishop of Cracow. City of Cracow described in the letters their problems such as tax rates, merchants avoiding to obey the storage law, threats from other armies. City hall referred in the correspondence to their privileges. Most of letters were written in Polish.

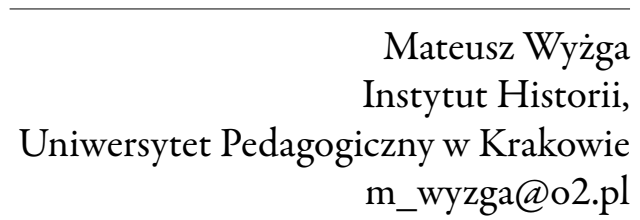

